\title{
Energy Saving Building Strategies through The Application of Solar Control Glass
}

\author{
NUR LAELA LATIFAH, ERWIN YUNIAR RAHADIAN
}

\author{
Department of Architecture, Institut Teknologi Nasional Bandung, Indonesia \\ Email: ela@itenas.ac.id
}

Received 2 Februari 2020 | Revised 11 Maret 2020 | Accepted 28 April 2020

\begin{abstract}
ABSTRAK
Sesuai dengan konsep Green Building, desain bangunan harus memperhatikan penghematan energi operasional bangunan. Semakin besar beban termal, maka semakin boros konsumsi energi listrik. Salah satu cara untuk menurunkan energi listrik adalah dengan mengurangi beban termal eksternal, sehingga pemilihan jenis solar control glass merupakan aspek yang sangat penting. Metoda analisis dilakukan secara kuantitatif. Sebagai kasus studi yaitu Gedung Kantor Pengelola Bendungan Sei Gong di Batam, dan berdasarkan perhitungan Calculator OTTV akan ditentukan alternatif solar control glass yang tepat agar memenuhi syarat dengan batas maksimal OTTV di Indonesia (45 Watt per meter persegi). Manfaat penelitian ini adalah memperoleh masukan pemilihan tipe kaca yang tepat berdasarkan SHGC, pada kasus bangunan kantor.
\end{abstract}

Kata kunci: Hemat energi operasional bangunan, Overall Thermal Transfer Value, Solar Control Glass, Solar Heat Gain Coefficient

\begin{abstract}
In accordance with the Green Building concept, building designs must pay attention to building operational energy savings. The greater the thermal load, the more wasteful the electricity consumption of the $A C$ system. One way to reduce $A C$ loads is to reduce external thermal loads, then choosing the type of solar control glass is a very important aspect. The method of analysis is done quantitatively. As a case study is Sei Gong Dam Management Office Building in Batam, and based on OTTV Calculator calculation an appropriate solar control glass alternative will be determined to meet the requirements with the maximum OTTV limit in Indonesia (45 Watt per square meter). The benefit of this research is to get input on selection of the right type of glass based on SHGC, in the case of office buildings.
\end{abstract}

Keywords: Energy saving on building operation, Overall Thermal Transfer Value, solar control glass, Solar Heat Gain Coefficient 
Energy Saving Building Strategies through The Application of Solar Control Glass in Office Building

\section{INTRODUCTION}

The use of electrical energy that is non-renewable and originates from the conversion of fossil fuels results in carbon emissions that trigger global warming. Non-renewable electrical energy is used to run mechanical and electrical equipment such as AC systems including artificial lighting systems. The huge consumption of electrical energy comes from the use of AC systems. By following with one of the principles of green building namely conserving energy, a building was built with the least possible use of fossil fuels in its operation (Ardiani, 2015). The building designs must pay attention to operational energy savings, to reduce carbon emissions triggering global warming. The greater the thermal load, the more wasteful energy consumption. One way to make a lower thermal load is to minimize the external load, through the design of the building envelope that can reduce the reception of solar thermal radiation into a room or building, so that based on calculations can be obtained Overall Thermal Transfer Value (OTTV) of less than $45 \mathrm{Watt} / \mathrm{m} 2$.

Office building with its function as a work area, so as not to rely on artificial lighting systems and can get enough sunlight as a source of natural lighting during the day, designed with the use of glass on the building envelope. Thin and transparent glass can transmit solar heat radiation far more than the wall. This will increase the external thermal load for the AC system, so choosing the type of solar control glass is a very important aspect so that the acquisition of Energy Transmittance (DET) and Solar Factor (SF) can be reduced. It is expected that through the application of glass with the right Solar Heat Gain Coefficient (SHGC), the DET and SF that enter the building can be suppressed (automatically decrease the external thermal load of the AC system) and finally with the acquisition of OTTV less than $45 \mathrm{~W} / \mathrm{m} 2$ can save energy use non-renewable electricity while supporting the green building concept.

\subsection{Relation of Energy Efficiency and Building Facade}

Buildings use the highest energy of total energy usage in the world, which amounts to 50 percent. Thermal transfer from the facade is a burden for the greatest cooler namely amounting to 45 percent, infiltration 20 percent, user 18 percent, heat from wall 9 percent, lighting 8 percent, and room heat 3 percent (Yusuf, 2010). Energy efficiency is now universally recognized as one of the quickest and most cost-effective ways to reduce energyrelated emissions associated with global warming, climate change, acid rain, and smog. The skin of the building acts as a barrier between the indoor environment and the outdoor environment (Vijayalaxmi, 2010).

The external cooling load of a building is primarily determined by its facade, where there are often conflicting demands of architecture, natural light, visual relationships with the outside world, and cooling load. The energy entering through a facade is determined by the total solar energy transmittance of the glazing and the shading factor of solar screening. The total solar energy transmittance can be influenced by coatings on the glass (solar control glass). It is possible to consider large window areas exposed to sunlight. In general terms, large window areas exposed to direct sunlight are only acceptable with exterior solar screening (Hausladen et al, 2006).

\subsection{Overall Thermal Transfer Value}

Overall Thermal Transfer Value (OTTV) is a measure of heat gain into the building through the building envelope. It also acts as an index for comparing the thermal performance of buildings (Vijayalaxmi, 2010). OTTV is more suitable for application to buildings in hot climates because it accounts for the solar heat gain at the building envelope (Yik \& Chan, 1995). Control of OTTV implies the control of heat transfer through the building envelope. 
Nur Laela Latifah, Erwin Yuniar Rahadian

More the OTTV, more is the heat gain inside the building through its envelope. If heat gain is controlled then the load on the air conditioner can be reduced, leading to lesser consumption of electricity. The concept of OTTV is based on the assumption that the envelope of a building is completely enclosed (Vijayalaxmi, 2010).

$$
\begin{aligned}
& \text { OTTV }=\alpha[\text { UW } \times(1-W W R)] \times \text { TDeq }+(S C \times W W R \times S F)+(\text { Uf } \times \text { WWR } \times \Delta T) \\
& (\text { Nasional, 2000 })
\end{aligned}
$$

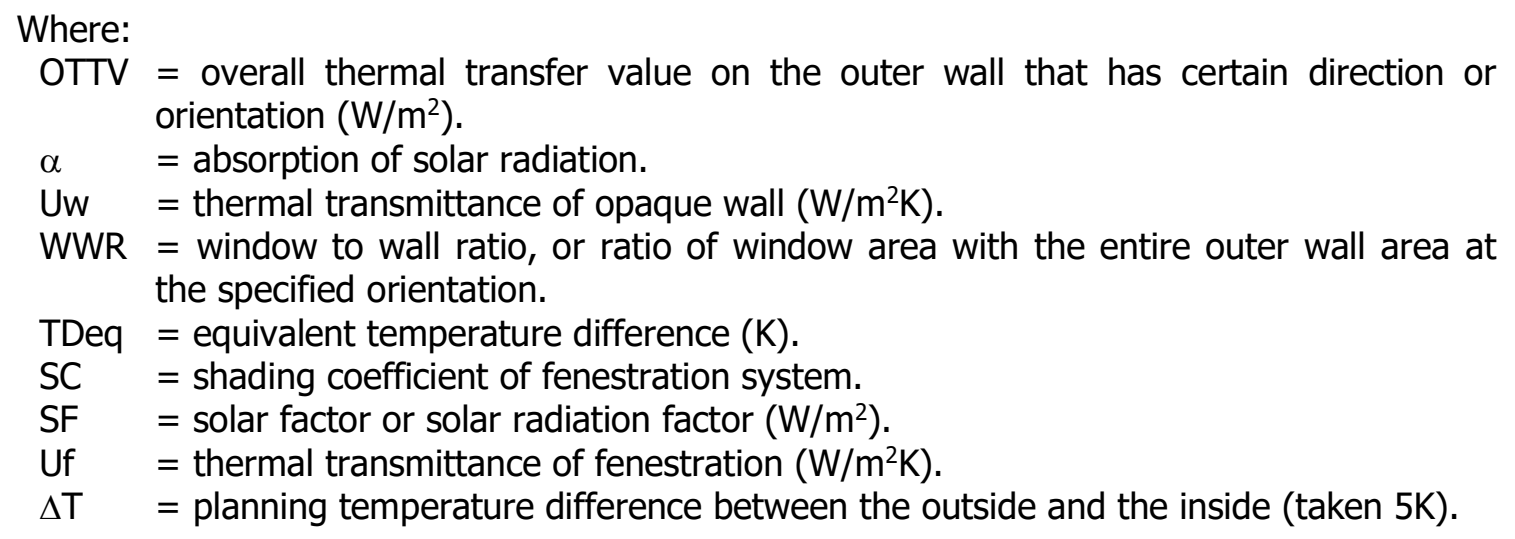

OTTV consists of three major components: (a) conduction through opaque walls, (b) conduction through window glass, and (c) solar radiation through window glass (Hui, 1997). The three important parameters on which OTTV depends are the architectural design parameters, the climatic parameters and the parameters pertaining to the local inhabitants. Building design parameters consist of building orientation, walling material, roofing material, envelope color, type of glass, shading of walls, and shading of windows. Climatic parameters consist of latitude, solar radiation, air temperature, wind speeds, humidity, and precipitation. Local parameter consists of indoor comfort conditions (Vijayalaxmi, 2010).

\subsection{Solar Control Glass}

Sunlight in the form of short waves enters through the glass and heats the objects inside, then turns into long waves that cannot break through the plane of glass (Karyono, 2013) Tempered Glass is not good in its function as a filter because it does not have the ability to reduce the reception of solar thermal radiation. The glass used should be the type with low Energy Transmittance (DET), so that the Shading Coefficient (SC) is low and automaticaly Solar Heat Gain Coefficient (SHGC) is low no more than 0.4 to meet green building requirements. SHGC is a coefficient that states the percentage of solar radiation received and transmitted directly and indirectly (absorbed and reradiated) into space, in numbers from 0 to 1 (Mediastika, 2019). The lower the SHGC, the less solar thermal radiation becomes an external thermal load for the AC system. Also, it would be better if the $U$ Value is not too high (no more than $5.0 \mathrm{~W} / \mathrm{m}^{2} \mathrm{~K}$ (Latifah \& Rahadian, 2018). Glass with as low a U-value as possible should be used in order to achieve a good level of thermal comfort. Glazing should not reflect light when viewed from outside (Hausladen, et al, 2006). With the same color, the thicker the glass, the lower SF and SHGC. With the same thickness, the darker the color of glass, the SF and SHGC are lower (Latifah, 2015).

\subsection{Sun Shading and Solar Screening}

Indonesia has a humid hot tropical climate that causes thermal discomfort. One form of the thermal control strategy is shade and filter. Sun shader is massive without holes, and no sunlight can still be transmitted. The sun filter is perforated and/ or transparent, so there is still solar heat radiation entering the room/ building. Examples of sun shaders are shading 
Energy Saving Building Strategies through The Application of Solar Control Glass in Office Building

devices, which can be in the form of subtracting building masses and fins. Examples of sun filters are solar control glass and secondary skin (Latifah, 2015).

The effectiveness of solar screening depends to a large extent on its position. External screening can be between three and five times as efficient, although it is exposed to the weather (Hausladen, et al, 2006). Based on 1993 research on several air-conditioned buildings in Jakarta, the use of electrical energy in buildings that have a sun barrier can reach $30 \%$ to $50 \%$ lower, at the same room temperature. This potential by preventing direct solar heating against the glass walls of the building envelope (Karyono, 2013).

\section{METHOD}

\subsection{Analysis Method}

The method of analysis is done quantitatively. As a design validation that the external load of solar thermal radiation on the building envelope has been safe to save the operational energy of the AC system, then an assessment is done using the Overall Thermal Transfer Value (OTTV) tool in the form of a spreadsheet and became one of the guidelines in designing green buildings in Bandung. As the OTTV limit is $45 \mathrm{~W} / \mathrm{m}^{2}$. There are 3 choices of cities, namely Bandung (less hot), Jakarta (hot), and Makassar (the hottest), so that they can be adapted to the needs based on the climatic conditions of other cities in Indonesia.

As the parameter for selecting solar control glass is the value of the Solar Heat Gain Coefficient (SHGC), which for climate and weather in Indonesia is not more than 0.40. SHGC $=0.86 \times \mathrm{SC}$, and this Shading Coefficient (SC) on glass is specifically based on color and thickness, as well as the position and amount of coating. With the same Window to Wall Ratio (WWR) value, the lower the SC, the lower the SHGC, so that Energy Transmittance (DET) and Solar Factor (SF) obtained in the buildings are also lower.

With the same type of glass, the higher the WWR, the average OTTV value will be even greater, so glass with a better thermal specification is needed. In this research, the selection of the right type of solar control glass will be examined in building with an office function and a WWR of no more than $50 \%$, so that the average OTTV meets the requirements (OTTV is attempted in each building's facade not to exceed the $45 \mathrm{~W} / \mathrm{m}^{2}$ limit).

\subsection{Case Study}

For the application of solar control glass to be effective, the design of the building must have supported the reduction of external thermal load reception. As a case study, the Sei Gong Dam Management Office in Batam where during the design process of mass orientation, mass composition forms, and wall and glass specifications have been determined.

The orientation of the building mass is north-south with a slight tilt $15^{\circ}$ away from the north counterclockwise. The height of the building is 2 floors and there is 4 facades setback with a certain distance so that the shading effect is obtained. In certain parts of the facade, there are secondary skins that also help reduce exposure to solar thermal radiation on glass and walls. The glass type in the building's original design in the form of Tempered Clear Glass SHGC 0.80 has a high external thermal load on the air conditioning system thereby increasing the electrical energy consumption of the building's operations. This is considered not by following the concept of green building which must save the use of electricity that is non-renewable, because it can increase carbon emissions triggering global warming. To that end, efforts will be made to improve through several of proposed design steps. 
Energy Saving Building Strategies through The Application of Solar Control Glass in Office Building

In this research, the acquisition of OTTV values that meet the requirements will be sought, with the condition of mass composition and the fixed opening area where WWR does not exceed 50\%. The Original Design was improved through a Proposed Design consisting of several steps (variants). The original design of the building has had a shade with a setback in certain parts of the east, south and west facades on the 1st floor and 2nd floor. In addition, there are secondary skins with fairly tight holes in the east and west facades of the 2nd floor perimeter of the building's mass. The type of glass still does not have good thermal specifications to provide protection against exposure to solar thermal radiation, and ACP walls are not equipped with thermal insulation.

The most important of glass thermal specifications consists of Energy Transmittance (DET, \%), Solar Factor (SF, \%), Shading Coefficient (SC, 0.0-1.0), Solar Heat Gain Coefficient (SHGC, $0.0-1.0)$, and $U$ Value $\left(\mathrm{W} / \mathrm{m}^{2} \mathrm{~K}\right)$. In the Proposed Design, an attempt is made to reduce exposure to solar thermal radiation mainly through the application of glass with better thermal specifications, especially through the selection of the right SHGC. To help this reduction, thermal insulation is given to the ACP wall. The composition of the mass of the building setback is still maintained, then there are still shading. Secondary skin is still maintained.

The Proposed Design consists of Variant 1, Variant 2, and Variant 3 based on SHGC differences as shown in Table 1, where the lower the SHGC, the lower DET and SF. SHGC can be obtained based on SC multiplication with a coefficient of 0.86 , and not too high, a maximum of 0.40 . All alternative types of glass have a thickness of $8 \mathrm{~mm}$ as needed and a bluish color is chosen in order to context with the building's function as the office of the dam manager and the color of the dam water around the site. Glass is also the type of single glass, not the type that is applied as insulated glass/ double glass. The selected glass is strived to be still affordable by the building construction budget, where the lower the SHGC, the more expensive the price tends to be.

Grating without glass (ventilation holes) in the facade walls are considered to have an SHGC of 0.86 because SC is a maximum of 1.00 under without glass conditions. If there is a secondary skin with holes that are quite tight, then it is assumed that the protected opening area is only $50 \%$.

Table 1. Conditions of OTTV Calculator Calculation

\begin{tabular}{|r|l|l|l|}
\hline No & Condition & $\begin{array}{l}\text { SHGC (Type of Glass) } \\
\text { ( } h \text { ttp://Www.amfg.co.id, 2017) }\end{array}$ & ACP with Thermal Insulation \\
\hline 1. & Original Design & 0.80 (Tempered Clear Glass) & No (Glass-Back Panel) \\
\hline 2. & Proposed Design Variant 1 & $0.35-0.40$ (Stopsol Glass) & Yes (Glass-Back Panel-Insulation) \\
\hline 3. & Proposed Design Variant 2 & $0.30-0.35$ (Sunergy Glass) & Yes (Glass-Back Panel-Insulation) \\
\hline 4. & Proposed Design Variant 3 & $<0.30$ (T-Sunlux Glass) & Yes (Glass-Back Panel-Insulation) \\
\hline
\end{tabular}

\subsection{OTTV Calculator Input}

\section{Identification of Exterior Wall Specification}

a) Number of wall construction types $=3$

b) Exterior wall specifications (EW).

Wall construction options available are Brick Wall, Glass-Back Panel, Glass-Back PanelInsulation, Hebel Wall, and Concrete Precast, with a certain color, as shown in Table 2 and Table 3. 
Table 2. Thermal Conductivity $(\lambda)$ and Density $(\rho)$ (Hausladen, G., Michael, M. de., and Liedl, 2006)

\begin{tabular}{|c|c|c|c|}
\hline No & Material & $\lambda(\mathbf{W} / \mathbf{m K})$ & $\rho\left(\mathbf{k g} / \mathbf{m}^{3}\right)$ \\
\hline 1. & Concrete, medium density & 1.35 & 2.000 \\
\hline 2. & Concrete, aerated & $0.11-0.31$ & $300-1.000$ \\
\hline 3. & Solid brick (fired clay) & $0.50-1.40$ & $1.000-2.400$ \\
\hline 4. & Aluminium & 160 & 2.800 \\
\hline
\end{tabular}

Table 3. Absorption of Solar Radiation (SNI 6389, 2000)

\begin{tabular}{|c|l|c|}
\hline No & Paint The Surface of The Outer Wall & $\alpha$ \\
\hline 1. & Black evenly & 0.95 \\
\hline 2. & Gray/ dark blue & 0.88 \\
\hline 3. & Medium brown & 0.84 \\
\hline 4. & Semi-gloss white & 0.30 \\
\hline 5. & White varnish & 0.21 \\
\hline
\end{tabular}

EW1 $=$ Hebel Wall construction that is the closest to lightweight brick, semi-gloss white color.

EW2 = Glass-Back Panel construction that is the closest to ACP without thermal insulation, gray color. EW3 $=$ Brick Wall construction which is the closest brick, medium brown color.

As the main material of the wall is EW1. The main material construction of the selected wall is Hebel which is aerated concrete, because it has a low thermal conductivity $(\lambda)$ of only 0.16 $\mathrm{W} / \mathrm{mK}$ and a quite low normal density ( $\rho$ ) of $575 \mathrm{~kg} / \mathrm{m}^{3}$ (http://www.hebel.co.id) spesifikasi/blok/blok-hebel, 2018). The main material color of the selected wall is semi-gloss white because it has a low absorption of solar radiation $(\alpha)$ of only 0.30 (Nasional, 2000). The lower thermal conductivity, density, and absorption of solar radiation, the lower OTTV is obtained. The dimensions of the walls and openings are calculated not including the dimensions of the columns and beams structure.

Diameter of the 1 st floor columns structure $=0.60 \mathrm{~m}$.

Dimensions of the 1st floor columns structure at grids 3D, 4D, 5D, and 6D $=0.6 \mathrm{~m} \times 1.6 \mathrm{~m}$. Dimensions of the 2nd floor columns structure $=0.40 \mathrm{~m} \times 0.40 \mathrm{~m}$.

Dimensions of the 2 nd floor columns structure at grids 3D, 4D, 5D, and 6D $=0.6 \mathrm{~m} \times 1.2 \mathrm{~m}$.

\section{Identification of Exterior Fenestration System Specification}

a) Exterior fenestration $(F)$ system specifications

$\mathrm{F}=$ type of exterior fenestration system, with its thermal specification

$\mathrm{SH}=$ outer shade specification code

b) Outer shade element details

$\mathrm{SH}=$ outer shade specification code, with its dimension and slope

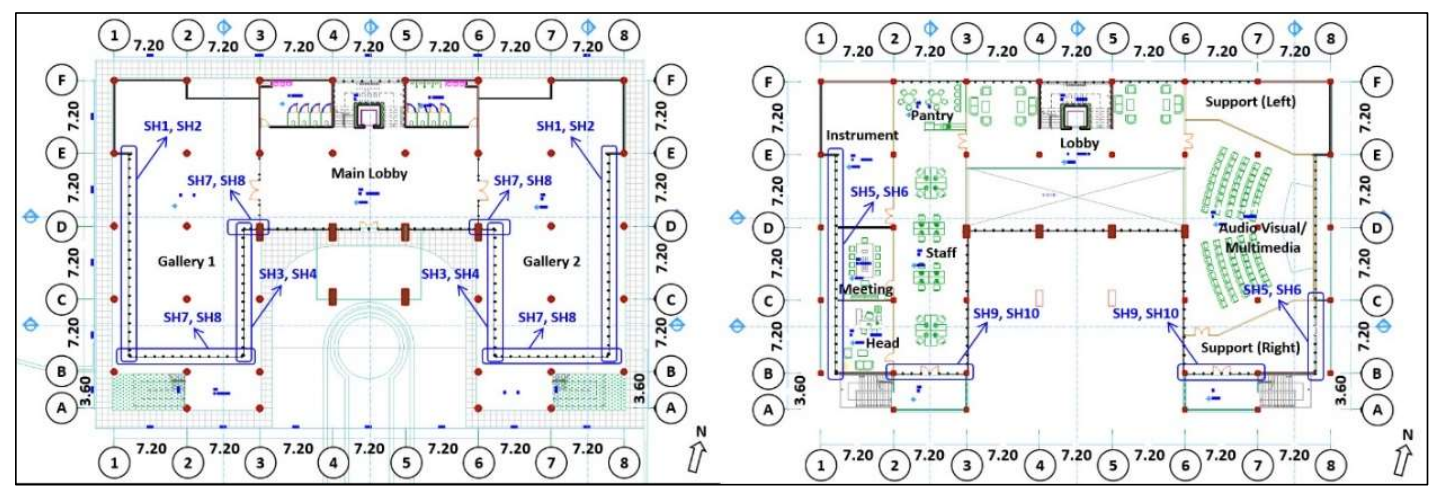

Figure 2. Allocation of Shade (Left: 1st floor; Right: 2nd floor) 


\section{Facade Identification}

The method used is Method 1 or Method 2 depending on the total number of facades which is analogous to the number of floors. Inputs include facade height (floor to floor distance), facade length, wall construction type (EW), fenestration system construction type (F), area/ specific opening area, and the total number of floors.

\section{Facade Input}

The entire facades are taken into calculation, with consideration of indoor comfort condition that affects each other between Lobby lounge on the 2nd floor which is connected via void and stair with Main Lobby on the 1st floor (open plan), and between Staff which is connected with Pantry (open plan), also related to Audio Visual/ Multimedia, Support (Right) can function as a reception lobby and Support (Left) as a backstage for presenters.

a) North facade (back elevation)

Facade orientation $=\mathrm{U}($ Utara $=$ North $)$. See at Figure 3 and Figure 4.

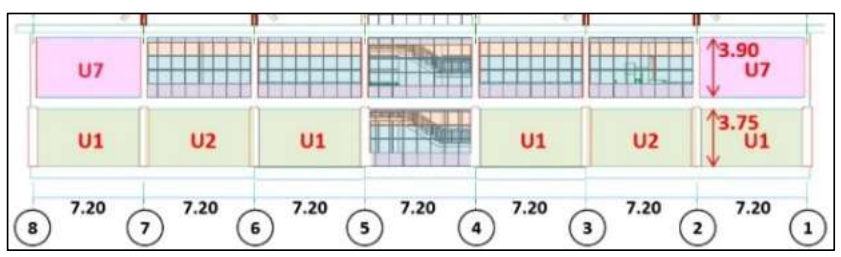

Figure 3. North Facade (Back Elevation) of 1st floor and 2nd floor

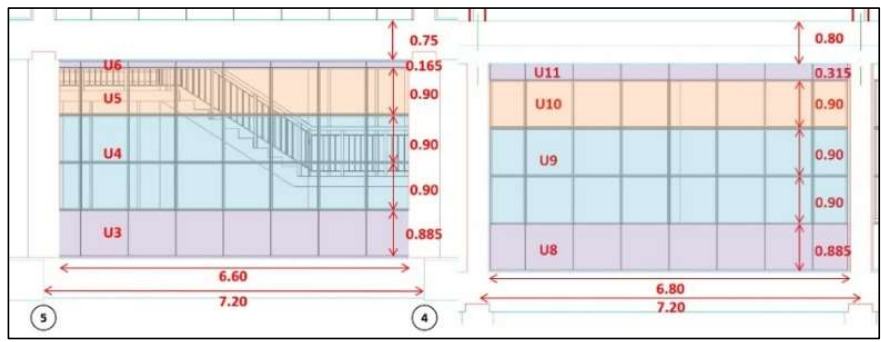

Figure 4. Left: North Facade 1st floor at grid 4-5; Right: North Facade 2nd floor at grid 6-7

b) East facade (left elevation)

Facade orientation $=\mathrm{T}($ Timur $=$ East $)$. See at Figure 5 and Figure 6 .

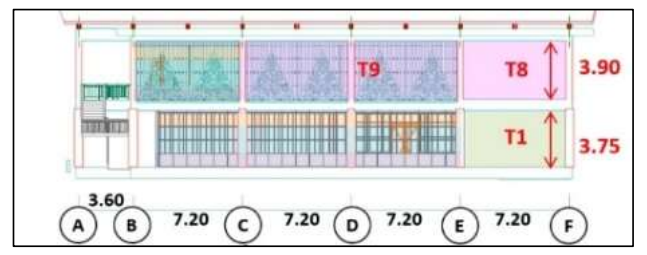

Figure 5. East Facade (Left Elevation) of 1st floor and 2nd floor 


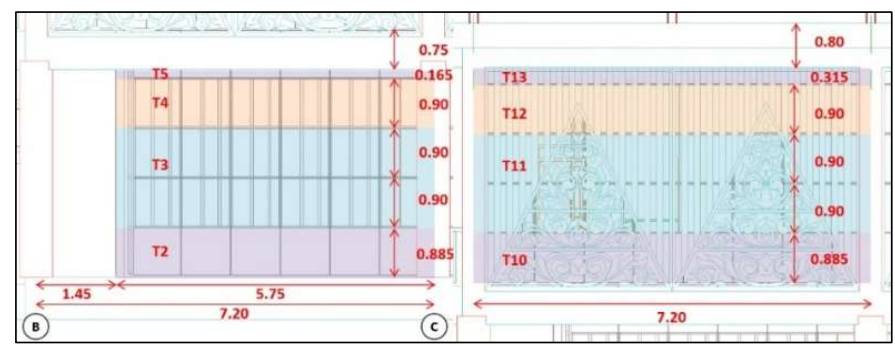

Figure 6. Left: East Facade 1st floor at grid B-C; Right: North Facade 2nd floor at grid B-C c) South facade (front elevation)

Facade orientation $=\mathrm{S}$ (Selatan $=$ South). See at Figure 7, Figure 8, Figure 9, and Figure 10.

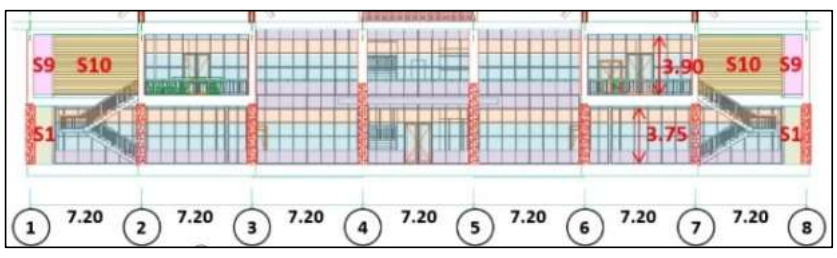

Figure 7. South Facade (Front Elevation) of 1st floor and 2nd floor

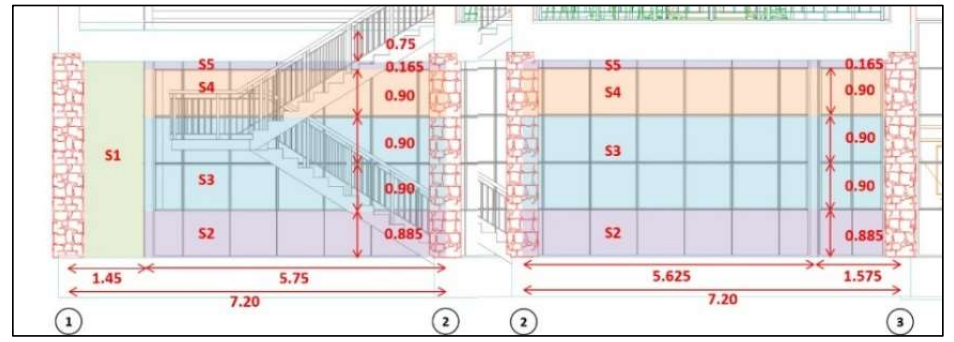

Figure 8. Left: South Facade 1st floor at grid 1-2; Right: South Facade 1st floor at grid 2-3

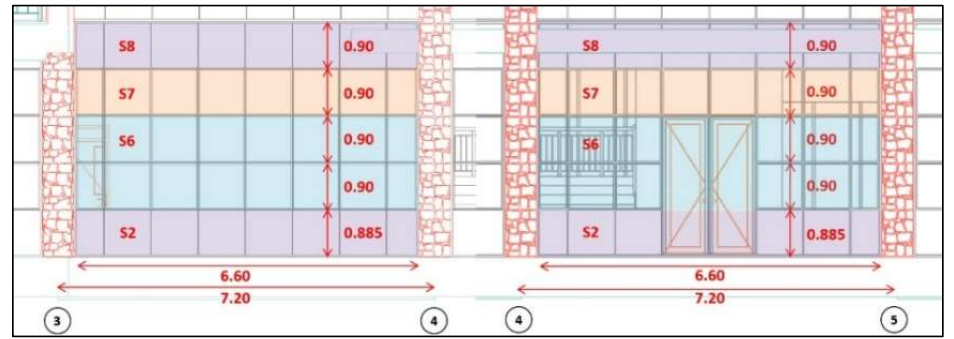

Figure 9. Left: South Facade 1st floor at grid 3-4; Right: South Facade 1st floor at grid 4-5

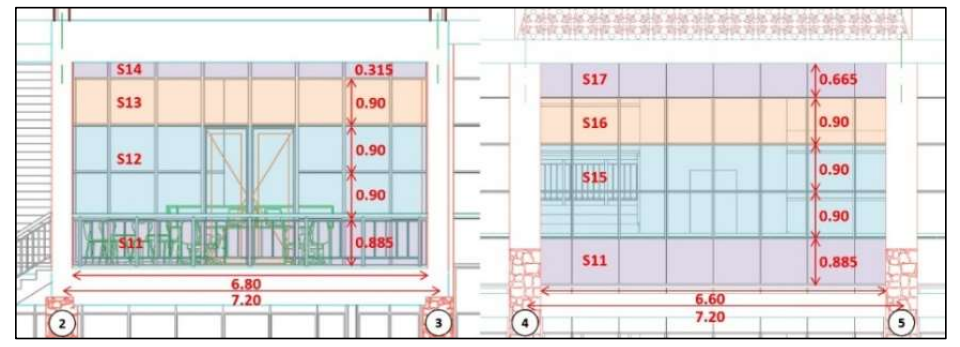

Figure 10. Left: South Facade 2nd floor at grid 2-3; Right: South Facade 2nd floor at grid 4-5 
d) West facade (right elevation)

Facade orientation $=\mathrm{B}$ (Barat $=$ West $)$. See at Figure 11 and Figure 12 .

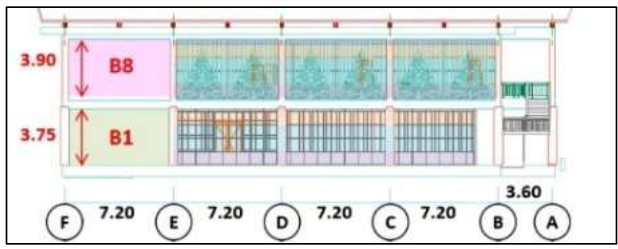

Figure 11. West Facade (Right Elevation) of 1st floor and 2nd floor

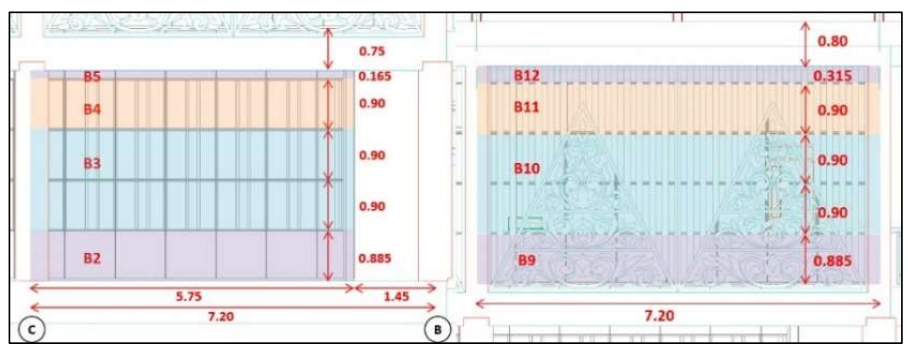

Figure 12. Left: West Facade 1st floor at grid B-C; Right: West Facade 2nd floor at grid B-C

\section{Thermal Specification of Glass}

The type of glass selected must have a maximum Shading Coefficient (SC) of 0.47 in order to get the maximum Solar Heat Gain Coefficient (SHGC) of 0.40 (SHGC $=0.86 \times \mathrm{SC}$, and SHGC $\leq 0.40$ ), so that the Energy Transmittance (DET) and Solar Factor (SF) obtained in the building are not high. See Table 4, Table 5, and Table 6.

Table 4. Proposed Design Variant 1 (SHGC 0.38 and 0.40)

\begin{tabular}{|r|l|c|c|c|l|c|}
\hline No & $\begin{array}{l}\text { Type of Coated Pyrolitic Glass (Stopsol) } \\
\text { (http://Www.amfg.co.id, 2017) }\end{array}$ & $\begin{array}{c}\text { DET } \\
(\%)\end{array}$ & $\begin{array}{c}\text { SF } \\
(\%)\end{array}$ & SC & SHGC & $\begin{array}{c}\text { U Value } \\
\left(\mathbf{W} / \mathbf{m}^{2} \mathbf{K}\right)\end{array}$ \\
\hline 1. & $\begin{array}{rlc}\text { Stopsol - } \\
\text { New Supersilver Blue Green 8 mm \#2 }\end{array}$ & 24 & 41 & 0.47 & $\begin{array}{l}=0.86 \times 0.47=0.4042 \\
=0.40\end{array}$ & 5.6 \\
\hline 2. & $\begin{array}{l}\text { Stopsol - } \\
\text { Classic Dark Blue 8 mm \#2 }\end{array}$ & 20 & 38 & 0.44 & $\begin{array}{l}=0.86 \times 0.44=0.3784 \\
=0.38\end{array}$ & 5.6 \\
\hline
\end{tabular}

Table 5. Proposed Design Variant 2 (SHGC 0.32, 0.34, and 0.35)

\begin{tabular}{|c|c|c|c|c|c|c|}
\hline No & $\begin{array}{l}\text { Type of Coated Pyrolitic Glass } \\
\text { (Sunergy) (http://Www.amfg.co.id, 2017) }\end{array}$ & $\begin{array}{l}\text { DET } \\
(\%)\end{array}$ & $\begin{array}{l}\text { SF } \\
(\%)\end{array}$ & SC & SHGC & $\begin{array}{l}\text { U Value } \\
\left(\mathbf{W} / \mathbf{m}^{2} K\right)\end{array}$ \\
\hline 1. & 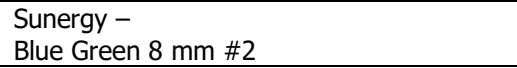 & 21 & 35 & 0.41 & $\begin{array}{l}=0.86 \times 0.41=0.3526 \\
=0.35\end{array}$ & 4.1 \\
\hline 2. & $\begin{array}{l}\text { Sunergy Sigma - } \\
\text { Dark Blue } 8 \mathrm{~mm} \# 2\end{array}$ & 20 & 34 & 0.39 & $\begin{array}{l}=0.86 \times 0.39=0.3354 \\
=0.34\end{array}$ & 4.4 \\
\hline 3. & $\begin{array}{l}\text { Sunergy Sigma - } \\
\text { Blue Green } 8 \mathrm{~mm} \# 2\end{array}$ & 18 & 32 & 0.37 & $\begin{array}{l}=0.86 \times 0.37=0.3182 \\
=0.32\end{array}$ & 4.3 \\
\hline
\end{tabular}

Table 6. Proposed Design Variant 3 (SHGC 0.19, 0.23, and 0.25)

\begin{tabular}{|r|l|c|c|c|l|c|}
\hline No & $\begin{array}{l}\text { Type of Coated Magnetron Glass } \\
\text { (T-Sunlux) (http://www.amfg.co.id, 2017) }\end{array}$ & $\begin{array}{c}\text { DET } \\
(\%)\end{array}$ & $\begin{array}{c}\text { SF } \\
(\%)\end{array}$ & SC & SHGC & $\begin{array}{c}\text { U Value } \\
\left(\mathbf{W} / \mathbf{m}^{2} \mathbf{K}\right)\end{array}$ \\
\hline 1. & $\begin{array}{l}\text { T-Sunlux - } \\
\text { On Dark Blue 520 8 mm \#2 }\end{array}$ & 7 & 25 & 0.29 & $\begin{array}{l}=0.86 \times 0.29=0.2494 \\
=0.25\end{array}$ & 4.8 \\
\hline 2. & $\begin{array}{l}\text { T-Sunlux - } \\
\text { On Dark Blue 514 8 mm \#2 }\end{array}$ & 23 & 0.27 & $\begin{array}{l}=0.86 \times 0.27=0.2322 \\
=0.23\end{array}$ & 4.6 \\
\hline 3. & $\begin{array}{l}\text { T-Sunlux - } \\
\text { On Dark Blue 508 8 mm \#2 }\end{array}$ & 0.22 & $\begin{array}{l}=0.86 \times 0.22=0.1892 \\
=0.19\end{array}$ & 4.3 \\
\hline
\end{tabular}




\section{OTTV Calculator Calculation Result}

Based on the calculation, the average Window to Wall Ratio (WWR) is $44.24 \%$. The south facade is the front of the building with the largest WWR to exceed $50 \%$, whereas the north facade is back of the building with the smallest WWR no more than 30\%. See Table 7.

\section{Table 7. Window to Wall Ratio}

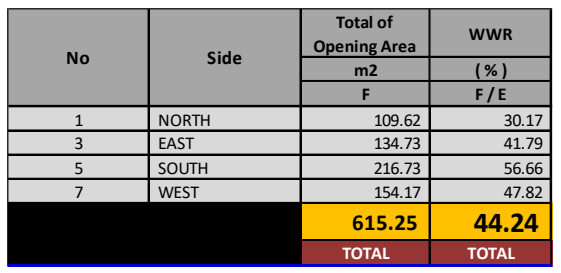

The OTTV summary tables shown here are the conditions of the Original Design, the Proposed Design of Variant 1 with the highest SHGC (0.40), the Proposed Design of Variant 3 with the lowest SHGC (0.19), as well as the conditions when achieving the 1 Star or 2 Star rating. 1 Star if OTTV reaches $45 \mathrm{~W} / \mathrm{m}^{2}, 2$ Star $35 \mathrm{~W} / \mathrm{m}^{2}$, and 3 Star $30 \mathrm{~W} / \mathrm{m}^{2}$. Regarding the fulfillment of OTTV requirements cannot be more than $45 \mathrm{~W} / \mathrm{m}^{2}$, the achievement is Yes or No. See Table 8 to Table 19.

a) Original Design ( $\mathrm{SHGC}=0.80$ )

Table 8. Original Design $(S H G C=0.80)$ - Left: Bandung; Middle: Jakarta; Right: Makassar

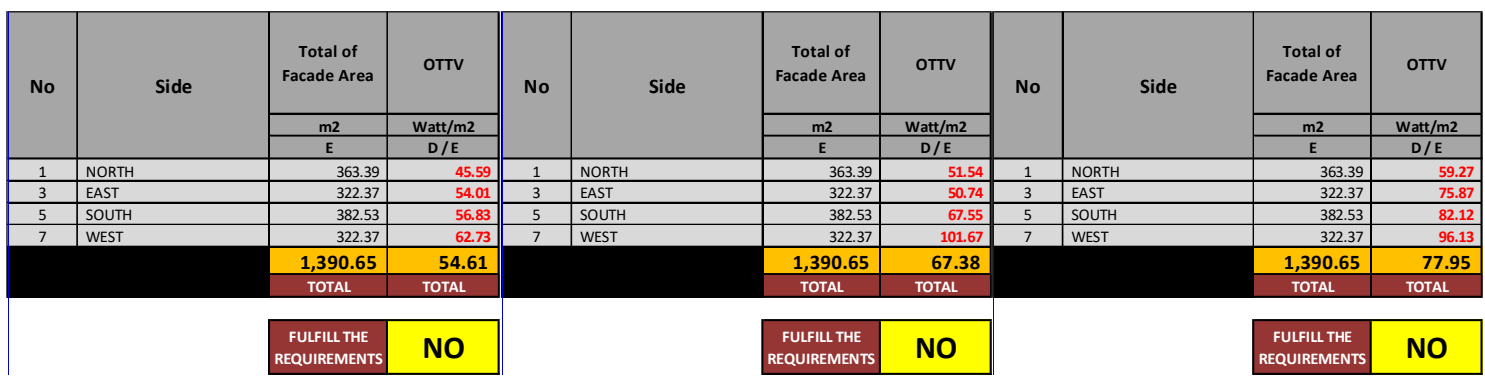

b) Proposed Design of Variant 1 with The Highest SHGC (0.40)

Table 9. Proposed Design Variant 1 (SHGC $=0.40)$ - Bandung
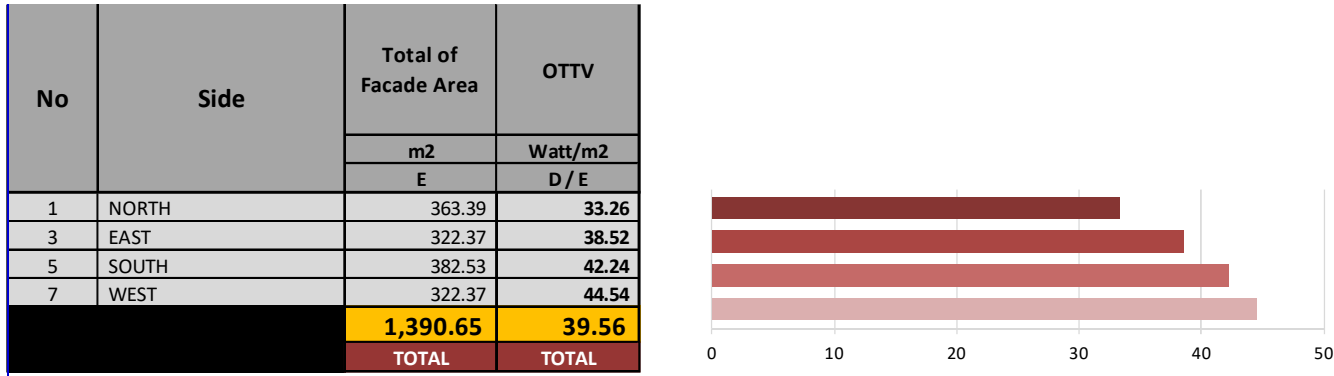

\begin{tabular}{|c|c|c|}
\hline $\begin{array}{c}\text { FULFIL THE } \\
\text { REQUUREMENTS }\end{array}$ & YES & 1 STAR \\
\hline
\end{tabular}


Table 10. Proposed Design Variant $1($ SHGC $=0.40)$ - Jakarta

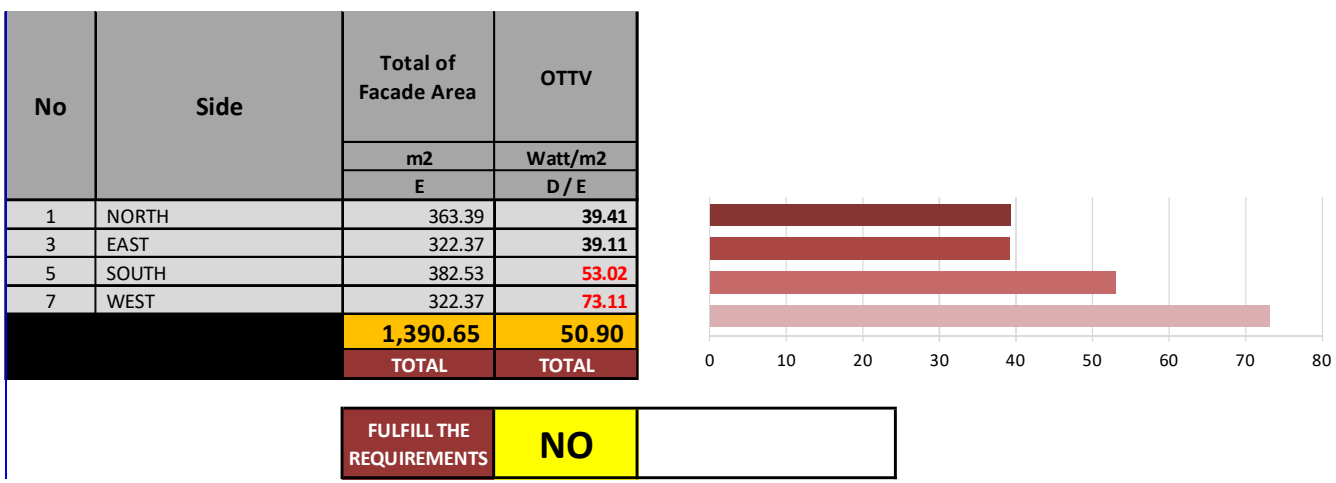

Table 11. Proposed Design Variant $1($ SHGC $=0.40)$ - Makassar
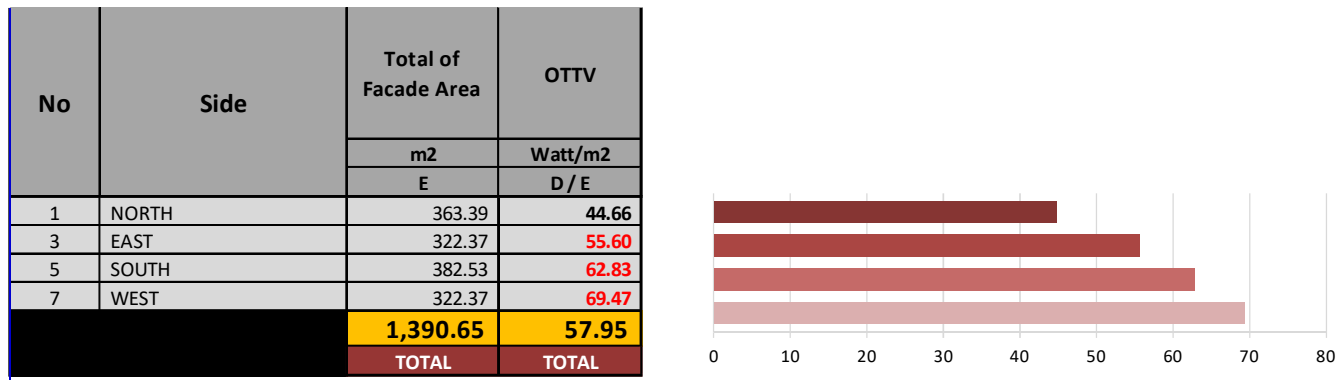

\begin{tabular}{|c|c|l|}
\hline FULFILL THE & NO & \\
REQUIREMENTS & NO \\
\hline
\end{tabular}

c) Proposed Design of Variant 3 with The Lowest SHGC (0.19)

Table 12. Proposed Design Variant $3($ SHGC $=0.19)-$ Bandung
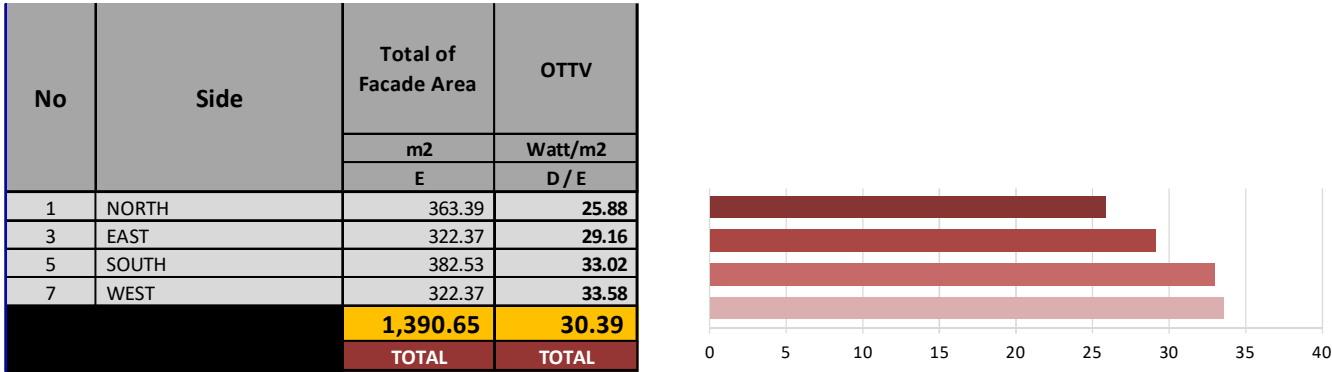

\begin{tabular}{|c|c|c|}
\hline $\begin{array}{c}\text { FULFILL THE } \\
\text { REQUIREMENTS }\end{array}$ & YES & 2 STAR \\
\hline
\end{tabular}

Table 13. Proposed Design Variant $3($ SHGC $=0.19)$ - Jakarta
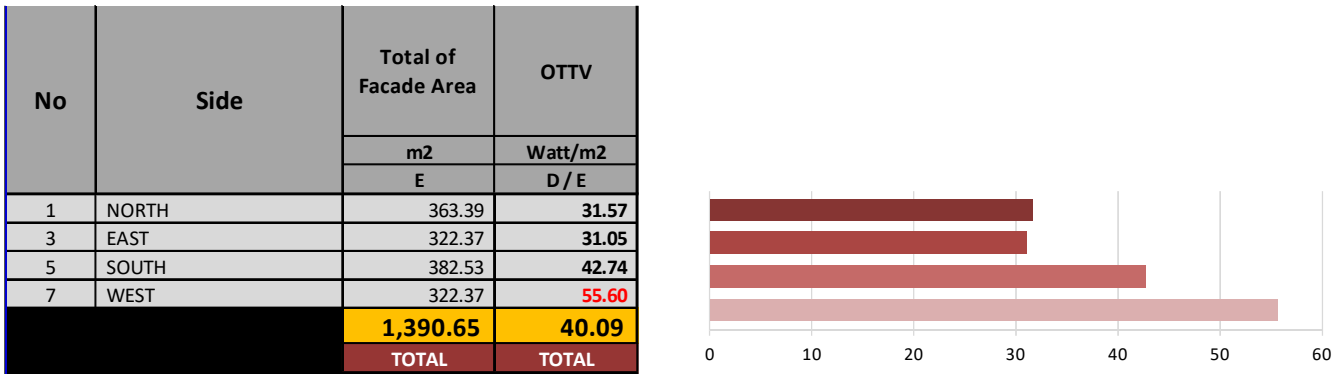

FULFILL THE REQUIREMENTS YES 1 STAR 
Table 14. Proposed Design Variant $3($ SHGC $=0.19)-$ Makassar

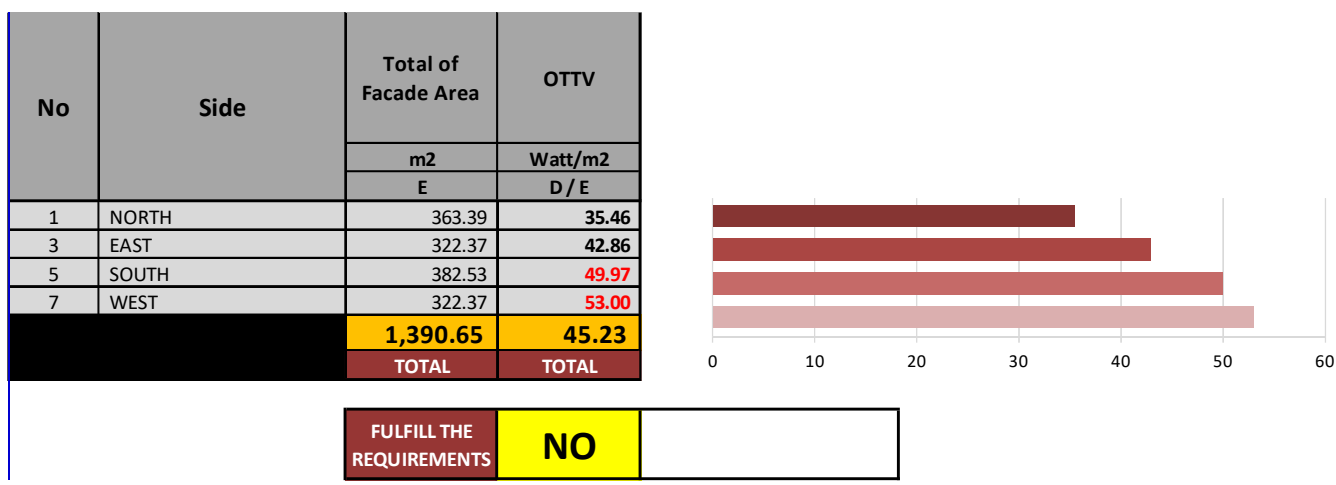

d) Proposed Design with 1 Star or 2 Star Rating

Table 15. Proposed Design Variant $3($ SHGC $=0.25)$ - Bandung

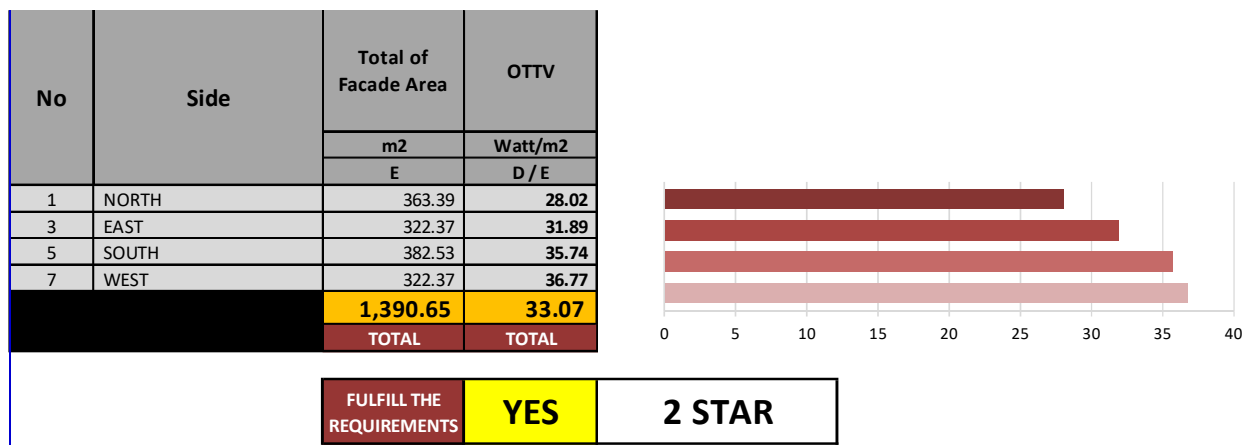

For Bandung location, the 2 Star rating can be achieved with SHGC $=0.25$.

Table 16. Proposed Design Variant $3($ SHGC $=0.25)$ - Jakarta

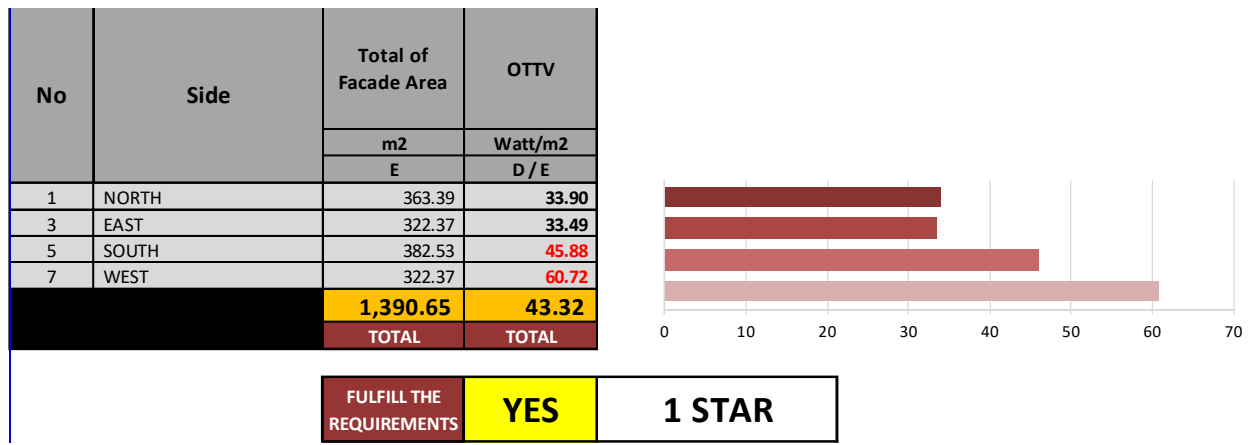

For Jakarta location, the 1 Star rating can be achieved with $\mathrm{SHGC}=0.25$.

e) OTTV Calculator Calculation Resume

Based on comparisons between the three cities Bandung, Jakarta, and Makassar, with the same glass thermal specifications, it is known that the lowest OTTV calculation results are in Bandung and the highest ones are in Makassar. With the highest SHGC 0.40, the 1 Star rating (OTTV $45 \mathrm{~W} / \mathrm{m}^{2}$ ) can already be achieved if the climate and weather conditions especially air temperature and solar heat radiation are identical to Bandung. This rating for Jakarta can be achieved with SHGC 0.25 while for Makassar it is not achieved even though the SHGC has the lowest 0.19 . The 2 Star rating (OTTV $35 \mathrm{~W} / \mathrm{m}^{2}$ ) can be achieved in Bandung with SHGC 0.25. Related to OTTV achievement, $\mathrm{N}=$ North facade, $\mathrm{E}=$ East, $\mathrm{S}=$ South, and W = West. See Table 17, Table 18, and Table 19. 
Table 17. OTTV Calculator Calculation Resume for Bandung Location

\begin{tabular}{|c|c|c|c|c|c|c|c|c|c|}
\hline \multirow{2}{*}{ No } & \multirow{2}{*}{$\begin{array}{l}\text { Glass type for Original Design } \\
\text { (SHGC 0.80) }\end{array}$} & \multirow{2}{*}{ SC } & \multirow{2}{*}{ SHGC } & \multirow{2}{*}{$\begin{array}{c}\text { Avg OTTV } \\
\left(\mathbf{W} / \mathbf{m}^{2}\right)\end{array}$} & \multicolumn{4}{|c|}{ OTTV Achievement } & \multirow{2}{*}{$\begin{array}{l}\text { Achievement, } \\
\text { Rating }\end{array}$} \\
\hline & & & & & $\mathbf{N}$ & $\mathbf{E}$ & $\mathbf{S}$ & $\mathbf{W}$ & \\
\hline 1. & Tempered Clear Glass $8 \mathrm{~mm}$ & 0.93 & 0.80 & 54.61 & $\mathrm{X}$ & $\bar{X}$ & $\mathrm{X}$ & $\mathrm{X}$ & No \\
\hline \multirow{2}{*}{ No } & \multirow{2}{*}{$\begin{array}{l}\text { Glass type for Proposed Design of Variant } 1 \\
\text { (SHGC } 0.38,0.40)\end{array}$} & \multirow{2}{*}{ SC } & \multirow{2}{*}{ SHGC } & \multirow{2}{*}{$\begin{array}{c}\text { Avg OTTV } \\
\left(\mathrm{W} / \mathbf{m}^{2}\right)\end{array}$} & \multicolumn{4}{|c|}{ OTTV Achievement } & \multirow{2}{*}{$\begin{array}{l}\text { Achievement, } \\
\text { Rating }\end{array}$} \\
\hline & & & & & $\mathbf{N}$ & $\mathbf{E}$ & $\mathbf{S}$ & W & \\
\hline 1. & Stopsol - New Supersilver Blue Green $8 \mathrm{~mm} \# 2$ & 0.47 & 0.40 & 39.56 & $\mathrm{OK}$ & $\mathrm{OK}$ & $\mathrm{OK}$ & $\mathrm{OK}$ & Yes, 1 Star \\
\hline 2. & Stopsol - Classic Dark Blue 8 mm \#2 & 0.44 & 0.38 & 38.59 & $\mathrm{OK}$ & $\mathrm{OK}$ & $\mathrm{OK}$ & $\mathrm{OK}$ & Yes, 1 Star \\
\hline \multirow{2}{*}{ No } & \multirow{2}{*}{$\begin{array}{l}\text { Glass type for Proposed Design of Variant } 2 \\
\text { (SHGC } 0.32,0.34,0.35)\end{array}$} & \multirow{2}{*}{ SC } & \multirow{2}{*}{ SHGC } & \multirow{2}{*}{$\begin{array}{c}\text { Avg OTTV } \\
\left(\mathbf{W} / \mathbf{m}^{2}\right)\end{array}$} & \multicolumn{4}{|c|}{ OTTV Achievement } & \multirow{2}{*}{$\begin{array}{l}\text { Achievement, } \\
\text { Rating }\end{array}$} \\
\hline & & & & & $\mathbf{N}$ & $\mathbf{E}$ & $\mathbf{S}$ & $\mathbf{W}$ & \\
\hline 1. & Sunergy - Blue Green $8 \mathrm{~mm} \# 2$ & 0.41 & 0.35 & 36.41 & $\mathrm{OK}$ & $\mathrm{OK}$ & $\mathrm{OK}$ & $\mathrm{OK}$ & Yes, 1 Star \\
\hline 2. & Sunergy Sig & 0.39 & 0.34 & & $\mathrm{OK}$ & $\mathrm{OK}$ & $\mathrm{OK}$ & $\mathrm{OK}$ & \\
\hline 3. & Sunergy Sigma - Blue Green $8 \mathrm{~mm} \# 2$ & 0.37 & 0.32 & 35.27 & $\mathrm{OK}$ & $\mathrm{OK}$ & $\mathrm{OK}$ & $\mathrm{OK}$ & Yes, 1 Star \\
\hline \multirow{2}{*}{ No } & \multirow{2}{*}{$\begin{array}{l}\text { Glass type for Proposed Design of Variant } 3 \\
\text { (SHGC } 0.19,0.23,0.25)\end{array}$} & \multirow{2}{*}{ SC } & \multirow{2}{*}{ SHGC } & \multirow{2}{*}{$\begin{array}{c}\text { Avg OTTV } \\
\left(\mathbf{W} / \mathrm{m}^{2}\right)\end{array}$} & \multicolumn{4}{|c|}{ OTTV Achievement } & \multirow{2}{*}{$\begin{array}{l}\text { Achievement, } \\
\text { Rating }\end{array}$} \\
\hline & & & & & $\mathbf{N}$ & $\mathbf{E}$ & $\mathbf{S}$ & $\mathbf{W}$ & \\
\hline 1. & T-Sunlux - On Dark Blue 5208 mm \#2 & 0.29 & 0.25 & $\mathbf{3 3 . 0 7}$ & $\mathrm{OK}$ & $\mathrm{OK}$ & $\mathrm{OK}$ & $\mathrm{OK}$ & Yes, 2 Star \\
\hline 2. & T-Sunlux - On Dark Blu & 0.27 & 0.23 & 32 & $\mathrm{OK}$ & $\mathrm{OK}$ & $\mathrm{OK}$ & $\mathrm{OK}$ & Yes, 2 Star \\
\hline 3. & T-Sunlux - On Dark Blue $5088 \mathrm{~mm} \# 2$ & 0.22 & 0.19 & 30.39 & $\mathrm{OK}$ & $\mathrm{OK}$ & $\mathrm{OK}$ & $\mathrm{OK}$ & Yes, 2 Star \\
\hline
\end{tabular}

Table 18. OTTV Calculator Calculation Resume for Jakarta Location

\begin{tabular}{|c|c|c|c|c|c|c|c|c|c|}
\hline \multirow{2}{*}{ No } & \multirow{2}{*}{$\begin{array}{l}\text { Glass type for Original Design } \\
\text { (SHGC 0.80) }\end{array}$} & \multirow{2}{*}{ SC } & \multirow{2}{*}{ SHGC } & \multirow{2}{*}{$\begin{array}{c}\text { Avg OTTV } \\
\left(\mathbf{W} / \mathbf{m}^{2}\right) \\
\end{array}$} & \multicolumn{4}{|c|}{ OTTV Achievement } & \multirow{2}{*}{$\begin{array}{l}\text { Achievement, } \\
\text { Rating }\end{array}$} \\
\hline & & & & & $\mathbf{N}$ & $\mathbf{E}$ & $\mathbf{S}$ & $\mathbf{W}$ & \\
\hline 1. & "Tempered Clear Glass $8 \mathrm{~mm}$ & 0.93 & 0.80 & $\begin{array}{l}67.38 \\
\end{array}$ & $\overline{\mathrm{X}}$ & $\overline{\mathrm{X}}$ & $\overline{\mathrm{X}}$ & $\overline{\mathrm{X}}$ & No \\
\hline \multirow{2}{*}{ No } & \multirow{2}{*}{$\begin{array}{l}\text { Glass type for Proposed Design of Variant } 1 \\
\text { (SHGC 0.38, 0.40) }\end{array}$} & \multirow{2}{*}{ SC } & \multirow{2}{*}{ SHGC } & \multirow{2}{*}{$\begin{array}{c}\text { Avg OTTV } \\
\left(\mathrm{W} / \mathbf{m}^{2}\right)\end{array}$} & \multicolumn{4}{|c|}{ OTTV Achievement } & \multirow{2}{*}{$\begin{array}{l}\text { Achievement, } \\
\text { Rating }\end{array}$} \\
\hline & & & & & $\mathbf{N}$ & $\mathbf{E}$ & $\mathbf{S}$ & $\mathbf{W}$ & \\
\hline 1. & Stopsol - New Supersilver Blue Green $8 \mathrm{~mm} \# 2$ & 0.47 & 0.40 & 50.90 & $\mathrm{OK}$ & $\mathrm{OK}$ & $\mathrm{X}$ & $\overline{\mathrm{X}}$ & No \\
\hline 2. & Stopsol - Classic Dark Blue 8 mm \#2 & 0.44 & 0.38 & 49.83 & $\mathrm{OK}$ & $\mathrm{OK}$ & $\mathrm{X}$ & $\mathrm{X}$ & No \\
\hline \multirow{2}{*}{ No } & \multirow{2}{*}{$\begin{array}{l}\text { Glass type for Proposed Design of Variant } 2 \\
\text { (SHGC } 0.32,0.34,0.35)\end{array}$} & \multirow{2}{*}{ SC } & \multirow{2}{*}{ SHGC } & \multirow{2}{*}{$\begin{array}{c}\text { Avg OTTV } \\
\left(\mathbf{W} / \mathbf{m}^{2}\right)\end{array}$} & \multicolumn{4}{|c|}{ OTTV Achievement } & \multirow{2}{*}{$\begin{array}{l}\text { Achievement, } \\
\text { Rating }\end{array}$} \\
\hline & & & & & $\mathbf{N}$ & $\mathbf{E}$ & $\mathbf{S}$ & $\mathbf{W}$ & \\
\hline 1. & Sunergy - Blue Green $8 \mathrm{~mm} \# 2$ & 0.41 & 0.35 & 46.54 & OK & OK & $\mathrm{X}$ & $\mathrm{X}$ & No \\
\hline 2. & Sunergy Sigma - Dark Blue $8 \mathrm{~mm} \# 2$ & 0.39 & 0.34 & 46.28 & $\mathrm{OK}$ & OK & $\mathrm{X}$ & $\mathrm{X}$ & No \\
\hline 3. & Sunergy Sigma - Blue Green $8 \mathrm{~mm} \# 2$ & 0.37 & 0.32 & 45.42 & $\mathrm{OK}$ & $\mathrm{OK}$ & $\mathrm{X}$ & $\mathrm{X}$ & No \\
\hline \multirow{2}{*}{ No } & \multirow{2}{*}{$\begin{array}{l}\text { Glass type for Proposed Design of Variant } 3 \\
\text { (SHGC 0.19, 0.23, 0.25) }\end{array}$} & \multirow{2}{*}{ SC } & \multirow{2}{*}{ SHGC } & \multirow{2}{*}{$\begin{array}{c}\text { Avg OTTV } \\
\left(\mathbf{W} / \mathbf{m}^{2}\right) \\
\end{array}$} & \multicolumn{4}{|c|}{ OTTV Achievement } & \multirow{2}{*}{$\begin{array}{l}\text { Achievement, } \\
\text { Rating }\end{array}$} \\
\hline & & & & & $\mathbf{N}$ & $\mathbf{E}$ & $\mathbf{S}$ & W & \\
\hline 1. & T-Sunlux - On Dark Blue $5208 \mathrm{~mm} \# 2$ & 0.29 & 0.25 & 43.32 & $\mathrm{OK}$ & $\mathrm{OK}$ & $\mathrm{X}$ & $\mathrm{X}$ & Yes, 1 Star \\
\hline 2. & T-Sunlux - On Dark Blue $5148 \mathrm{~mm} \# 2$ & 0.27 & 0.23 & 42.31 & $\mathrm{OK}$ & $\mathrm{OK}$ & $\mathrm{OK}$ & $\mathrm{X}$ & Yes, 1 Star \\
\hline 3. & T-Sunlux - On Dark Blue $5088 \mathrm{~mm} \# 2$ & 0.22 & 0.19 & 40.09 & $\mathrm{OK}$ & $\mathrm{OK}$ & $\mathrm{OK}$ & $\mathrm{X}$ & Yes, 1 Star \\
\hline
\end{tabular}

Table 19. OTTV Calculator Calculation Resume for Makassar Location

\begin{tabular}{|c|c|c|c|c|c|c|c|c|c|}
\hline \multirow{2}{*}{ No } & \multirow{2}{*}{$\begin{array}{l}\text { Glass type for Original Design } \\
\text { (SHGC 0.80) }\end{array}$} & \multirow{2}{*}{ SC } & \multirow{2}{*}{ SHGC } & \multirow{2}{*}{$\begin{array}{c}\text { Avg OTTV } \\
\left(\mathbf{W} / \mathrm{m}^{2}\right)\end{array}$} & \multicolumn{4}{|c|}{ OTTV Achievement } & \multirow{2}{*}{$\begin{array}{l}\text { Achievement, } \\
\text { Rating }\end{array}$} \\
\hline & & & & & $\mathbf{N}$ & $\mathbf{E}$ & $\mathbf{S}$ & $\mathbf{W}$ & \\
\hline 1. & Tempered Clear Glass $8 \mathrm{~mm}$ & 0.93 & 0.80 & 77.95 & $\overline{\mathrm{X}}$ & $\overline{\mathrm{X}}$ & X & $\overline{\mathrm{X}}$ & No \\
\hline \multirow{2}{*}{ No } & \multirow{2}{*}{$\begin{array}{l}\text { Glass type for Proposed Design of Variant } 1 \\
\text { (SHGC 0.38, 0.40) }\end{array}$} & \multirow{2}{*}{ SC } & \multirow{2}{*}{ SHGC } & \multirow{2}{*}{$\begin{array}{c}\text { Avg OTTV } \\
\left(\mathbf{W} / \mathbf{m}^{2}\right)\end{array}$} & \multicolumn{4}{|c|}{ OTTV Achievement } & \multirow{2}{*}{$\begin{array}{l}\text { Achievement, } \\
\text { Rating }\end{array}$} \\
\hline & & & & & $\mathbf{N}$ & $\mathbf{E}$ & $\mathbf{S}$ & $\mathbf{W}$ & \\
\hline 1. & Stopsol - New Supersilver Blue Green $8 \mathrm{~mm} \# 2$ & 0.47 & 0.40 & $\mathbf{5 7 . 9 5}$ & OK & X & X & X & No \\
\hline 2. & Stopsol - Classic Dark Blue $8 \mathrm{~mm} \# 2$ & 0.44 & 0.38 & 56.65 & $\mathrm{OK}$ & $\mathrm{X}$ & $\mathrm{X}$ & $\mathrm{X}$ & No \\
\hline \multirow{2}{*}{ No } & \multirow{2}{*}{$\begin{array}{l}\text { Glass type for Proposed Design of Variant } 2 \\
\text { (SHGC 0.32, 0.34, 0.35) }\end{array}$} & \multirow{2}{*}{ SC } & \multirow{2}{*}{ SHGC } & \multirow{2}{*}{$\begin{array}{c}\text { Avg OTTV } \\
\left(\mathbf{W} / \mathbf{m}^{2}\right)\end{array}$} & \multicolumn{4}{|c|}{ OTTV Achievement } & \multirow{2}{*}{$\begin{array}{l}\text { Achievement, } \\
\text { Rating }\end{array}$} \\
\hline & & & & & $\mathbf{N}$ & $\mathbf{E}$ & $\mathbf{S}$ & $\mathbf{W}$ & \\
\hline 1. & Sunergy - Blue Green $8 \mathrm{~mm} \# 2$ & 0.41 & 0.35 & 53.14 & $\mathrm{OK}$ & $\mathrm{X}$ & $\mathrm{X}$ & $\mathrm{X}$ & No \\
\hline 2. & Sunergy Sigma - Dark Blue $8 \mathrm{~mm} \# 2$ & 0.39 & 0.34 & 52.72 & OK & $\mathrm{X}$ & $\mathrm{X}$ & $\mathrm{X}$ & No \\
\hline 3. & Sunergy Sigma - Blue Green $8 \mathrm{~mm} \# 2$ & 0.37 & 0.32 & 51.71 & $\mathrm{OK}$ & $\mathrm{X}$ & $\mathrm{X}$ & $\mathrm{X}$ & No \\
\hline \multirow{2}{*}{ No } & \multirow{2}{*}{$\begin{array}{l}\text { Glass type for Proposed Design of Variant } 3 \\
\text { (SHGC 0.19, 0.23, 0.25) }\end{array}$} & \multirow{2}{*}{ SC } & \multirow{2}{*}{ SHGC } & \multirow{2}{*}{$\begin{array}{c}\text { Avg OTTV } \\
\left(\mathbf{W} / \mathbf{m}^{2}\right)\end{array}$} & \multicolumn{4}{|c|}{ OTTV Achievement } & \multirow{2}{*}{$\begin{array}{l}\text { Achievement, } \\
\text { Rating }\end{array}$} \\
\hline & & & & & $\mathbf{N}$ & $\mathbf{E}$ & $\mathbf{S}$ & $\mathbf{W}$ & \\
\hline 1. & T-Sunlux - On Dark Blue 5208 mm \#2 & 0.29 & 0.25 & 48.99 & $\overline{\mathrm{OOK}}$ & $\mathrm{X}$ & $\mathrm{X}$ & $\mathrm{X}$ & No \\
\hline 2. & T-Sunlux - On Dark Blue 5148 mm \#2 & 0.27 & 0.23 & 47.83 & OK & $\mathrm{X}$ & $\mathrm{X}$ & $\mathrm{X}$ & No \\
\hline 3. & T-Sunlux - On Dark Blue 5088 mm \#2 & 0.22 & 0.19 & 45.23 & $\mathrm{OK}$ & $\mathrm{OK}$ & $\mathrm{X}$ & $\mathrm{X}$ & No \\
\hline
\end{tabular}

\section{CONCLUSION}

The selection of solar control glass must be based on climatic and weather conditions, especially air temperature and solar thermal radiation. Calculation of OTTV Calculator can be 
done by referring to 3 city conditions namely less hot (Bandung), hot (Jakarta), and the hottest (Makassar). The more hot the city, the protection ability of solar control glass must be better, where SC and SHGC must be lower so that Energy Transmittance (DET) and Solar Factor (SF) that enter the building can be reduced and finally the average OTTV can meet the requirements not more than the $45 \mathrm{Watt} / \mathrm{m}^{2}$ limit. Better yet, if OTTV in each building's facade meets this requirement. For this reason, a glass with a maximum SC of 0.47 is selected and the SHGC obtained automatically is no more than 0.40 . Based on research with a case study of an office building with an average WWR of no more than $50 \%(44.24 \%)$ and have been designed to help reduce the reception of solar thermal radiation, the lowest OTTV calculation results are in Bandung and the highest ones in Makassar. Solar control glass with SHGC 0.40 can already be applied to a less hot condition like Bandung. Solar control glass with SHGC 0.32, 0.34, and 0.35 has not been successful in the hottest and hottest conditions. Hot condition like Jakarta requires a solar control glass with a maximum SHGC of 0.25 , whereas in very hot condition such as Makassar, it has not succeeded in achieving OTTV requirements despite using glass with SHGC 0.19. To help OTTV meet the requirements, a number of significant strategies can be implemented, such as reducing the WWR, limiting the $U$ Value to no more than $5.0 \mathrm{~W} / \mathrm{m}^{2} \mathrm{~K}$, and increasing sun shading and solar screening (enlarge the dimensions of the shade fins, deepen the subtraction of the building, and increase the density of the secondary skin holes).

\section{REFERENCES}

Ardiani, Y. M. (2015). Sustainable Architecture: Arsitektur Berkelanjutan (1st ed.; A. M. Drajat, Ed.). Jakarta: Erlangga.

Hausladen, G., Michael, M. de., and Liedl, P. (2006). Climate Skin. Birkhausser.

Hui, S. C. M. (1997). Overall Thermal Transfer Value (OTTV): How to Improve Its Control in Hong Kong. Proceedings of the One-Day Symposium on Building, ENergy and Environment, (pp. 12-1-12-11). Retrieved from http://web.hku.hk/ cmhui/bse97a.pdf

Karyono, T. H. (2013). Third World Tropical Architecture and Cities A Case Study of Indonesia, Arsitektur dan Kota Tropis Dunia Ketiga Suatu Bahasan tentang Indonesia. Jakarta: Rajawali Pers.

Latifah, N. L. (2015). Building Physics 1, Fisika Bangunan 1 (1st ed.). Jakarta: Griya Kreasi.

Latifah, N. L., \& Rahadian, E. Y. (2018). Strategi Green Building untuk Optimalisasi Penghematan Energi Operasional Bangunan terkait Rancangan Ventilasi dan Pengkondisian Udara pada Gedung Kantor Pengelola Bendungan Sei Gong - Batam. Retrieved from https://www.google.com/url?sa=t\&rct=j\&q=\&esrc=s\&source=web $\& c d=2 \& c a d=$ rja\&uact $=8 \&$ ved $=2$ ahUKEwjvvt2_tvPIAhWRxTgGHZZwD5UQFjABegQIAR AC\&url=http\%3A\%2F\%2Feprints.itenas.ac.id\%2F235\%2F1\%2FA2\%2520Strategi\%2520Green\%2520Building.pdf\&usg=AOvVaw1kskTBgBGXMjPfplsdB $6 z i$ 
Energy Saving Building Strategies through The Application of Solar Control Glass in Office Building

Mediastika, C. E. (2019). Kaca Untuk Bangunan (1st ed.). Yogyakarta: Andi Offset.

Nasional, B. S. (2000). SNI 03-6389-2000 Konservasi energi selubung bangunan pada bangunan gedung, (pp. 1-39). Jakarta.

Vijayalaxmi, J. (2010). Concept of Overall Thermal Transfer Value (OTTV) in Design of Building Envelope to Achieve Energy Efficiency. International Journal of Thermal and Environmental Engineering, 1(2), 75-80. https://doi.org/10.5383/ijtee.01.02.003

Yusuf, A. A. (2010). Climate Change Issues and Mitigation Actions in Indonesia. Asia Climate Change Policy Forum 27-28 October 2010. 